\title{
PENGARUH PENGUNGKAPAN KINERJA EKONOMI, LINGKUNGAN DAN SOSIAL TERHADAP KINERJA KEUANGAN PADA PERUSAHAAN YANG TERDAFTAR DI BURSA EFEK INDONESIA TAHUN 2016-2018
}

\author{
Deslicintya Hutasoit ${ }^{1}$; Yan Christin Br. Sembiring ${ }^{2}$ \\ ${ }^{1,2)}$ Fakultas Ekonomi Program Studi Akuntansi Universitas Katolik Santo Thomas \\ deslicintyahutasoit@gmail.com ${ }^{1}$ \\ yanchristin11@gmail.com ${ }^{2}$
}

\begin{abstract}
ABSTRAK
Penelitian bertujuan untuk mengetahui pengaruh pengungkapan kinerja ekonomi, lingkungan dan sosial terhadap kinerja keuangan pada perusahaan yang terdaftar di Bursa Efek Indonesia (BEI). Populasi dalam penelitian ini merupakan semua perusahaan yang terdaftar di Bursa Efek Indonesia selama tahun 2016-2018. Teknik pengumpulan sampel yang digunakan adalah purposive sampling dengan jumlah sampel 23 perusahaan. Data diperoleh dari Bursa Efek Indonesia tahun 2016-2018. Teknik analisis data yang digunakan adalah regresi linear berganda dengan tingkat signifikan 5\%. Hasil uji secara parsial menunjukkan bahwa Kinerja Ekonomi dan Kinerja Sosial berpengaruh positif dan signifikan terhadap Kinerja Keuangan dan Kinerja Lingkungan tidak berpengaruh terhadap Kinerja Keuangan. Dimana ketika Kinerja Ekonomi berpengaruh positif terhadap Kinerja Keuangan maka kinerja Keuangannya naik. Dan ketika Kinerja Sosial berpengaruh positif dan signifikan terhadap Kinerja Keuangan maka Kinerja Keuangan naik. Hasil uji secara simultan menunjukkan bahwa Kinerja Ekonomi, Kinerja lingkungan dan kinerja sosial secara bersama-sama berpengaruh signifikan terhadap kinerja keuangan.
\end{abstract}

Kata kunci : Kinerja Ekonomi, Kinerja Lingkungan, Kinerja Sosial, dan Kinerja Keuangan.

\section{PENDAHULUAN}

Tujuan normatif perusahaan dalam melakukan kegiatan bisnis adalah memberikan kemakmuran bagi pemegang saham. Selain itu bertujuan untuk memberikan manfaat ekonomi dan mengalokasikan sumber daya secara efisien Winarto (2005). Kemakmuran pemegang saham akan dapat dicapai apabila perusahaan memiliki kinerja keuangan yang baik dari kegiatan bisnis yang dijalankan. Kieso et al. (2010, p. 1339) menjelaskan tren beberapa perusahaan yang mulai menggunakan bagian komentar manajemen (management commentary section) dalam laporan keuangan untuk mengungkapkan kinerja mereka terkait keberlanjutan (sustainability) perusahaan. Laporan tambahan yang berhubungan dengan keberlanjutan (sustainability) merupakan poin penting karena 
mengindikasikan perusahaan telah melakukan tanggungjawab sosial dan lingkungan sehingga dapat menyediakan informasi tentang prospek bisnis perusahaan di masa mendatang.

Manajemen perusahaan dilema antara mencapai kemakmuran pemegang saham yang ditentukan oleh angka laba perusahaan dengan mencapai kemakmuran lingkungan, ekonomi, dan keadaan sosial kultural masyarakat sekitar. Sebab, laba merupakan indikator kinerja keuangan perusahaan di masa depan, maka seringkali laba dijadikan dasar dalam pengambilan keputusan ekonomi. Sedangkan, dilain sisi perusahaan mempunyai tangggungjawab untuk peduli terhadap dampak yang ditimbulkan operasi perusahaan. Dilematika antara dua fenomena tersebut akan memberikan ruang bagi manajer untuk melakukan praktik manajemen laba. Bagaimanapun juga, seorang manajer mempunyai kebebasan untuk menaikkkan dan menurunkan laba tanpa melanggar Prinsip Akuntansi Berlaku Umum (PABU), karena PABU memberikan keleluasaan bagi manajer untuk melaporkan laba perusahaan. Namun, ada konsekuensi negatif yang diterima seorang manajer yang melakukan manajemen laba secara sengaja yaitu dapat mengancam reputasi dan karier dari manajer yang bersangkutan. Sehingga, manajer akan melakukan strategi pertahanan diri (entrenchment strategy) untuk mencegah ketidakpuasan pemegang kunci (stakeholder) ketika ia melaporkan kinerja keuangan perusahaan yang tidak memuaskan. Strategi itu dilakukan untuk melindungi image perusahaan dan reputasi manajer itu sendiri. Salah satu cara yang dilakukan manajer adalah membuat kebijakan perusahaan yang peduli terhadap kemakmuran lingkungan, ekonomi, dan keadaan sosial kultural masyarakat sekitar. Peningkatan kinerja lingkungan, kinerja ekonomi, dan kinerja sosial perusahaan akan membangun image positif perusahaan sehingga akan meningkatkan kinerja keuanganperusahaan.

Salah satu pengungkapan yang dapat dilakukan oleh perusahaan adalah Sustainabilty Report. Sustainablity Report adalah praktik dalam mengukur dan mengungkapkan aktivitas perusahaan sebagai tanggung jawab kepada seluruh stakeholders mengenai kinerja organisasi dalam mewujudkan tujuan pembangunan berkelanjutan. Sustainability Report bagi perusahaan merupakan publikasi informasi yang mencerminkan kinerja organisasi dalam dimensi ekonomi, sosial dan lingkungan yang dapat menjadi media bagi perusahaan untuk menginformasikan kinerja organisasi kepada seluruh pemangku kepentingan (Stakeholder). Bagi perusahaan pengungkapan sustainability report menjadi hal yang sangat 
penting. Hal ini dikarenakan sustainability report memuat laporan non keuangan perusahaan.

Sustainability Report berfungsi untuk menginformasikan bagaimana kinerja ekonomi, kinerja lingkungan dan kinerja sosial dari perusahaan. Sustainability Report diterbitkan sebagai suatu bentuk bukti pertanggungjawaban perusahaan kepada para pemangku kepentingan (stakeholder) dan bukti bahwa perusahaan berada di dalam batasan peraturan yang berlaku. Perusahaan perlu melakukan pengungkapan Sustainability Report dengan tujuan untuk memperoleh kepercayaan para pemangku kepentingan. Kepercayaan para pemangku kepentingan tersebut dapat berupa investasi maupun kerjasama dan memiliki potensi untuk meningkatkan produktifitas dan penjualan perusahaan. Peningkatan produktivitas dan penjualan perusahaan akan memberikan pengaruh terhadap tingkat laba bersih perusahaan (net income), dimana peningkatan laba bersih perusahaan akan meningkatkan Return on Asset pada perusahaan. Nilai Return on Asset perusahaan yang mengalami peningkatan dapat diartikan bahwa kinerja keuangan perusahaan mengalami peningkatan.

Pengungkapan kinerja ekonomi dalam Sustainability Report berpengaruh pada kinerja perusahaan yang diproksikan pada profitabilitas yang dalam hal ini adalah ROA. Sebagai bagian dari stakeholder, pemegang saham perlu adanya transparansi informasi terkait kinerja ekonomi perusahaan. Dengan adanya informasi mengenai kinerja ekonomi perusahaan, pemegang saham dapat memberikan kebijakan. Dari kebijakan - kebijakan yang diambil oleh stakeholders inilah perusahaan dituntut untuk dapat meningkatkan tingkat laba bersih perusahaan agar pemegang saham tidak menarik kembali saham mereka. Kepercayaan dari pemegang saham akan mendorong perusahaan untuk meningkatkan tingkat laba bersih mereka dari total asset yang ada.

Yohanes Kurniawan Susanto dan Josua Tarigan (2013) dengan judul Pengaruh Pengungkapan Sustainability Report Terhadap Profitabilitas perusahaan dengan hasil penelitian menyatakan bahwa hasil penelitian menunjukkan bahwa hanya pengungkapan kinerja sosial dan pengungkapan kinerja tanggung jawab produk yang mempengaruhi kinerja keuangan perusahaan. Junita Simbolon dan Dr.H.Memed Sueb, 2016 dengan judul pengaruh pengungkapan substainabilitya report terhadap kinerja perusahaan Studi empiris pada perusahaan tambang dan infrastruktur sub sektor energy yang terdaftar di BEI tahun 2010-2014 dengan hadir penelitian menyatakan bahwa kinerja ekonomi berpengaruh 
signifikan terhadap kinerja keuangan sedangkan kinerja lingkungan dan sosial tidak berpengaruh terhadap kinerja keuangan.

Wijayanti (2016) dengan judul Pengaruh Pengungkapan Sustainability Report Terhadap Kinerja Keuangan Perusahaan dengan hasil penelitian menyatakan pengungkapan lingkungan, berpengaruh terhadap kinerja keuangan perusahaan yang diproksikan dengan profitabilitas (return on asset).

Dea Eka Manis, F. Defung (2017) dengan judul pengaruh pengungkapan substainability report terhadap kinerja keuangan perusahaan infrastruktur yang terdaftar di bursa efek indonesia dengan hasil penelitian menyatakan bahwa hanya pengungkapan kinerja sosial dan pengungkapan kinerja tanggungjawab produk yang mempengaruhi kinerja keuangan perusahaan.

Berdasarkan fenomena diatas dan hasil penelitian terdahulu yang berbeda-beda maka penelitian ini ingin menguji Pengaruh Pengungkapan Kinerja Ekonomi, Lingkungan dan Sosial terhadap Kinerja Keuangan pada Perusahaan yang Terdaftar di Bursa Efek Indonesia tahun 2016-2018.

\section{TELAAH TEORI}

\section{Telaah Teori}

\section{a. Stakeholder Theory}

Teori stakeholder pada dasarnya adalah suatu teori yang menggambarkan kepada pihak mana saja perusahaan yang melakukan pertanggung jawaban terhadap sosial dan lingkungan (Freeman, 2009). Stakeholder theory memperluas tanggung jawab organisasi kepada seluruh pemangku kepentingan tidak hanya kepada investor atau pemilik.

Stakeholder theory menjelaskan bahwa keberadaan perusahaan tidak dapat dipisahkan dari para pemangku kepentingan (stakeholders). Para pemangku kepentingan secara langsung atau tidak langsung mempengaruhi dan dipengaruhi oleh perusahaan. Stakeholder adalah sekelompok orang atau individu yang dapat mempengaruhi atau dipengaruhi oleh kesuksesan atau kegagalan dari organisasi (Dewi et al., 2014)

\section{b.SR (Substainability Report)}

Menurut OJK (2017), SR (laporan keberlanjutan) merupakan bentuk laporan yang diterbitkan oleh perusahaan dalam rangka untuk melakukan pengungkapan (disclose) atau mengkomunikasikan kepada para pemangku kepentingan mengenai kinerja Lingkungan, Sosial dan Tata 
kelola yang baik (LST) secara akuntabel. Menurut GRI (2013), Global Reporting Initiative (GRI) merupakan lembaga pemberi pedoman pengungkapan sustainability report, mendefinisikan sustainability report sebagai praktik dalam mengukur dan mengungkapkan dampak ekonomi, lingkungan, dan sosial dalam aktivitas perusahaan sehari-hari, serta sebagai tanggung jawab kepada stakeholder internal dan eksternal mengenai kinerja organisasi dalam mewujudkan tujuan pembangunan berkelanjutan. Daftar Istilah Standar GRI ini diterbitkan oleh Global Sustainability Standards Board (GSSB) untuk digunakan bersama-sama dengan Standar Pelaporan Keberlanjutan GRI (Standar GRI) Laporan kebelanjutan adalah praktik dalam mengukur dan mengungkapkan aktivitas perusahaan sebagai tanggung jawab kepada seluruh stakeholders mengenai kinerja organisasi dalam mewujudkan tujuan pembangunan berkelanjutan.

\section{c. Kinerja Keuangan}

Kinerja keuangan adalah suatu analisis yang dilakukan untuk melihat sejauh mana suatu perusahaan telah melaksanakan dengan menggunakan aturan- aturan pelaksanaan keuangan secara baik dan benar. (Jumingan, 2006:239) gambaran kondisi keuangan perusahaan pada suatu periode tertentu baik menyangkut aspek penghimpunan dana maupun penyaluran dana, yang biasanya diukur dengan indikator kecukupan modal, likuiditas, dan profitabilitas. (Sutrisno, 2009:53) prestasi yang dicapai perusahaan dalam suatu periode tertentu yang mencerminkan tingkat kesehatan perusahaan tersebut.

\section{d. Kinerja Ekonomi}

Kinerja ekonomi (Economic Performance)diungkapkan dalam laporan tahunan perusahaan. Pada era perekonomian pasar yang disertai dengan terwujudnya kondisi kinerja ekonomi yang baik, efisien dan membawa keuntungan besar bagi perusahaan tetapi juga perlu disertai adanya perilaku kinerja ekonomi berkualitas etis yaitu perwujudan tanggung jawab sosial perusahaan secara baik. Almilia dan Wijayanto (2007) menyatakan bahwa kinerja ekonomi adalah kinerja perusahaan secara relatif berubah dari tahun ke tahun dalam suatu industri yang sama ditandai dengan tahunan perusahaan. 


\section{Aspek-aspek Kinerja Ekonomi}

\begin{tabular}{|l|l|}
\hline $\begin{array}{l}\text { PPM } \\
\text { Ekonomi }\end{array}$ & Keterangan \\
\hline EC1 & $\begin{array}{l}\text { Nilai ekonomi langsung yang dihasilkan dan dibagikan, termasuk } \\
\text { pendaptan, biaya operasi, komponen karyawan, donasi dan investasi } \\
\text { masyarakat lainnya, upah yang didapat dan pembayaran kepada pemberi } \\
\text { modal dan pemerintah }\end{array}$ \\
\hline EC2 & $\begin{array}{l}\text { Implikasi finansial, resiko dan peluang lainnya terhadap organisasi } \\
\text { sehubungan dengan perubahan iklim. }\end{array}$ \\
\hline EC5 & $\begin{array}{l}\text { Cakupan rasio tingkatan gaji standar untuk karyawan pemula dibandingkan } \\
\text { dengan upah minimun setempat dilokasi penting operasi }\end{array}$ \\
\hline EC6 & $\begin{array}{l}\text { Kebijakan, praktek dan proporsi pengeluaran untuk Supplier lokal dilokasi } \\
\text { penting operasi }\end{array}$ \\
\hline EC7 & $\begin{array}{l}\text { Prosedur untuk rekrutmen setempat dan proporsi manajemen senior yang } \\
\text { direkrut dari masyarakat setempat di lokasi penting operasi }\end{array}$ \\
\hline EC9 & $\begin{array}{l}\text { Pembangunan serta dampak investasi infrastruktur dan jasa yang disediakan } \\
\text { terutama untuk kepentingan publik, lewat pelibatan komersil, bantuan } \\
\text { material atau probono }\end{array}$ \\
\hline
\end{tabular}

Sumber : GRI G3

\section{e. Kinerja Lingkungan}

Kinerja Lingkungan (Environmental Performance) masalah yang ditimbulkan dari kegiatan operasi perusahaan berupa perusahaan lingkungan dari perusahaan seperti yang bergerak di bidang pertambangan, mendorong munculnya praktik akuntansi lingkungan sebagai alat pertanggungjawaban atau akuntabilitas publik atas usaha yang dilakukan perusahaan Sudjoko (2011).

\section{Apek-aspek Kinerja Lingkungan}

\begin{tabular}{|l|l|}
\hline $\begin{array}{l}\text { PPM } \\
\text { Lingkungan }\end{array}$ & Keterangan \\
\hline EN1 & Material yang digunakan berdasarkan berat atau volume. \\
\hline EN2 & Persentasi material yang digunakan, yang merupakan material daur ulang. \\
\hline EN3 & Direct energy consumption by primary energy source. \\
\hline EN4 & Konsumsi energi langsung dari sumber daya primer. \\
\hline EN5 & Penghematan energi lewat konservasi dan peningkatan penghematan. \\
\hline EN5 & Penghematan enerji lewat konservasi dan peninkatan pengahasilan. \\
\hline EN6 & $\begin{array}{l}\text { Inisiatif untuk penyediaan hemat-energi atau energy terbaharui berdasarkan } \\
\text { hasil produksi dan jasa, dan pengurangan kebutuhan energy sebagai akibat } \\
\text { inisiatif tersebut. }\end{array}$ \\
\hline EN7 & Inisiatif untuk pengurangan konsumsi energy tidak langsung dan hasilnya. \\
\hline EN8 & Jumlah total air yang daimbil dari sumbernya. \\
\hline EN9 & Sumber air yang terpengaruh secara signifikan akibat pengambilan air. \\
\hline
\end{tabular}




\begin{tabular}{|c|c|}
\hline EN10 & Persentase dan volume total air yang didaur ulang dan dipergunakan kembali. \\
\hline EN11 & $\begin{array}{l}\text { Lokasi dan luas tanah milik, sewa, yang dikelola, diatas berdampingan dengan } \\
\text { kawasan yang dilindungi dan kawasan dengan nilai keanekaragaman hayati } \\
\text { yang tinggi diluar kawasan yang dilindungi. }\end{array}$ \\
\hline EN12 & $\begin{array}{l}\text { Deskripsi dampak penting dari aktivitas, hasil produksi dan jasa terhadap } \\
\text { keaneka-ragaman hayati dikawasan yang dilindungi dan kawasan dengan nilai } \\
\text { diversitas tinggi diluar kawasan yang dilindungi. }\end{array}$ \\
\hline EN13 & Habitat yang dilindungi dan dipulihkan. \\
\hline EN14 & $\begin{array}{l}\text { Strategi, tindakan yang diambil, dan rencana kedepan untuk menangani } \\
\text { dampak terhadap keaneka-ragaman hayati. }\end{array}$ \\
\hline EN15 & $\begin{array}{l}\text { Jumlah spesies berdasarkan IUCN Red List dan konservasi nasional yang } \\
\text { habitatnya berada di kawasan terkena dampak operasi, berdasarkan tingkat } \\
\text { risiko kepunahan. }\end{array}$ \\
\hline EN16 & Total emisi gas rumah kaca lainnya yang relevan, berdasarkan berat. \\
\hline EN17 & Emisi gas rumah kaca lainnya yang relevan, berdasarkan berat. \\
\hline EN18 & $\begin{array}{l}\text { Inisiatif untuk mengurangi emisi gas rumah kaca dan pengurangan yang } \\
\text { tercapai. }\end{array}$ \\
\hline EN19 & Emisi substansi yang mengurangi lapisan ozon, berdasarkan berat. \\
\hline EN20 & NOx, Sox, dan emisi udara penting lainnya, berdasarkan jenis dan berat. \\
\hline EN21 & Jumlah total air yang dialirkan berdasarkan kualitas dan tujuan. \\
\hline EN22 & Berat total limbah, berdasarkan jenis dan metode pembuangan. \\
\hline EN23 & Jumlah total dan volume tumpahan yang signifikan. \\
\hline EN24 & $\begin{array}{l}\text { Berat limbah yang diangkut, impor dan ekspor ataupun dikelola yang } \\
\text { dianggap limbah B3 berdasarkan Based Convention Annex I, II,III, dan VIII, } \\
\text { dan persentase limbah yang diangkut dan dikirimkan ke luar negeri. }\end{array}$ \\
\hline EN25 & $\begin{array}{l}\text { Identitas, besaran, status dilindungi, dan nilai keanekaragaman hayati DAS } \\
\text { dan habitat terkait yang secara signifikan terkena dampak akibat pelaporan } \\
\text { organisasi tentang pembuangan air dan tumpahannya. }\end{array}$ \\
\hline EN26 & $\begin{array}{l}\text { Inisiatif untuk memitigasi damoak lingkungan dari hasil produk dan usaha, } \\
\text { dan batasan mitigasi dampaknya. }\end{array}$ \\
\hline EN27 & $\begin{array}{l}\text { Persentase barang-barang yang dijual beserta bahan pembungkus, yang di } \\
\text { peroleh kembali, berdasarkan kategori. }\end{array}$ \\
\hline EN28 & $\begin{array}{l}\text { Nilai moneter denda signifikan dan jumlah sanksi non-moneter untuk ketidak } \\
\text { patuhan terhadap undang-undang dan peraturan lungkungan. }\end{array}$ \\
\hline EN29 & $\begin{array}{l}\text { Dampak lingkungan penting akibat pengiriman barang-barang produksi dan } \\
\text { bahan-bahan yang digunakan untuk operasi perusahaan, maupun pengiriman } \\
\text { karyawan. }\end{array}$ \\
\hline EN30 & $\begin{array}{l}\text { Total pengeluaran dan investasi untuk perlindungan lingkungan, berdasarkan } \\
\text { jenis. }\end{array}$ \\
\hline
\end{tabular}

Sumber :GRI G3 


\section{f. Kinerja Sosial}

Darwin (2004), tanggung jawab sosial perusahaan merupakan suatu konsep bahan organisasi khususnya perusahaan, memiliki tanggung jawab terhadao konsumen, karyawan, pemegang saham, komunitas, dan lingkungan dalam segala aspek operasional perusahaan.

Aspek-aspek kinerja sosial

\begin{tabular}{|c|c|}
\hline $\begin{array}{l}\text { Kateg } \\
\text { Masy: }\end{array}$ & $\begin{array}{l}\text { sosial (termasuk HAM, Tenaga Kerja, Tanggung jawab Pr } \\
\text { at) }\end{array}$ \\
\hline PPM & \\
\hline HR1 & $\begin{array}{l}\text { Persentase dan jumlah total perjanjian investasi yang signifikan klausul HAM } \\
\text { atau yang telah melalui proses screening HAM }\end{array}$ \\
\hline HR2 & $\begin{array}{l}\text { Persentase kontraktor dan pemasok penting yang telah melalui prosese } \\
\text { screening HAM dan tindakan yang telah diambil }\end{array}$ \\
\hline HR3 & $\begin{array}{l}\text { Jumlah jam untuk pelatihan karyawan untuk kebijakan dan prosedur terkait } \\
\text { aspek HAM yang relevan untuk operasional, termasuk persentase jumlah } \\
\text { karyawan yang telah mendapat pelatihan }\end{array}$ \\
\hline HR4 & Jumlah total insiden terkait diskriminasi dan tindakan yang telah diambil \\
\hline HR5 & $\begin{array}{l}\text { Identifikasi kemungkinan adanya risiko operasi yang signifikan terkait hak atas } \\
\text { kebebasan berorganisasi dan berunding bersama, dan tindakan yang telah } \\
\text { diambil untuk mendukung hal tersebut }\end{array}$ \\
\hline HR6 & $\begin{array}{l}\text { Identifikasi kemungkinan adanya risiko opersai yang signifikan terjadinya } \\
\text { insiden tenaga kerja dibawah umur, dan tindakan-tindakan yang telah diambil } \\
\text { untuk membantu penghapusan tenga kerja dibawah umur }\end{array}$ \\
\hline HR7 & $\begin{array}{l}\text { Identifikasi kemungkinan adanya risiko operasi signifikan terjadinya insiden } \\
\text { akibat perbudakan atau kerja paksa, dan tindakan-tindakan yang diambil untuk } \\
\text { membantu penghapusan kerja paksa atau wajib kerja }\end{array}$ \\
\hline HR8 & $\begin{array}{l}\text { Persentase personel keamanan yang mendapat pelatihan kebijakan dan prosedur } \\
\text { organisasi terkait aspek HAM yang relevan terhadap operasi. }\end{array}$ \\
\hline HR9 & $\begin{array}{l}\text { Jumlah total pelanggan hak masyarakat adat dan tindakan-tindakan yang } \\
\text { diambil }\end{array}$ \\
\hline $\mathrm{PPN}$ & arakt \\
\hline $\mathrm{SO} 1$ & $\begin{array}{l}\text { Sifat, jangkauan dan efektivitas program dan praktek yang menilai dan } \\
\text { mengelolah dampak opersai terhadap masyarakat, termasuk tahapan masuk, } \\
\text { beroperasi dan selesai. }\end{array}$ \\
\hline $\mathrm{SO} 2$ & $\begin{array}{l}\text { Persentase dan jumlah total unit usaha yang dianalisa untuk risiko terkait } \\
\text { korupsi }\end{array}$ \\
\hline SO3 & $\begin{array}{l}\text { Persentase karyawan yang mendapat pelatihan kebijakan dan prosedur } \\
\text { organisasi terkait korupsi }\end{array}$ \\
\hline SO4 & Tindakan yang diambil untuk merespon insiden terkait korupsi \\
\hline SO5 & $\begin{array}{l}\text { Posisi dan partisipasi kebijakan public dalam pengenmbangan dan lobi } \\
\text { kebijakan public }\end{array}$ \\
\hline SO6 & $\begin{array}{l}\text { ibusi keuangan maupun barang yang dibe } \\
\text { dan institusi sejenis, berdasarkan tempat ber }\end{array}$ \\
\hline
\end{tabular}




\begin{tabular}{|c|c|}
\hline SO7 & $\begin{array}{l}\text { Jumlah total tindakan hokum yang diambil terhadap tindakan anti-kompetitif, } \\
\text { anti-perserikatan, praktek monopoli dan hasilnya }\end{array}$ \\
\hline SO8 & $\begin{array}{l}\text { Nilai dari denda signifikan dan jumlah total sanksi berbentuk bukan uang untuk } \\
\text { ketidak-patuhan terhadap hokum dan peraturan }\end{array}$ \\
\hline \multicolumn{2}{|c|}{ PPM Tenaga Kerja } \\
\hline LA1 & $\begin{array}{l}\text { Jumlah tenaga kerja berdasarkan jenis hubungan kerja, kontrak kerja, dan } \\
\text { wilayah }\end{array}$ \\
\hline LA2 & $\begin{array}{l}\text { Jumlah total dan rasio keluar masuk karyawan berdasarkan kelompok umur, } \\
\text { jenis kelamin dan wilayah }\end{array}$ \\
\hline LA3 & $\begin{array}{l}\text { Benefit yang disediakan untuk karyawan tetap yeng tersedia untuk kayawan } \\
\text { kontrak atau paruh waktu, berdasarkan operasi utama }\end{array}$ \\
\hline LA4 & Persentase karyawan yang tercakup dalam perjanjian perundingan bersama \\
\hline LA5 & $\begin{array}{l}\text { Jangka waktu pemberitahuan minimum terkait perubahan penting dari operasi, } \\
\text { termasuk apakah itu disebutkan dalam perjanjian bersama }\end{array}$ \\
\hline LA6 & $\begin{array}{l}\text { Persentase jumlah tenaga kerja yang terwakilkan dalam komite formal } \\
\text { manajemen-karywan untuk kesehatan dan keselamatan, yang membantu } \\
\text { memonitor dan memberi saran untuk program keselamatan dan kesehatan kerja }\end{array}$ \\
\hline LA7 & $\begin{array}{l}\text { Rasio kecelakaan, penyakit yang disebabkan pekerjaan, hari yang hilang, absen, } \\
\text { dan kecelakaan fatal ditempat kerja, berdsarkan wilayah }\end{array}$ \\
\hline LA8 & $\begin{array}{l}\text { Pendidikan, pelatihan, konseling, pencegahan, dan program pengawasan risiko } \\
\text { yang ada untuk membantu karyawan, keluarga, atau anggota, masyarakat terkait } \\
\text { penyakit serius }\end{array}$ \\
\hline LA9 & $\begin{array}{l}\text { Masalah-masalah kesehatan dan keselamatan yang tercakup dalam perjanjian } \\
\text { formal dengan serikat kerja }\end{array}$ \\
\hline LA10 & $\begin{array}{l}\text { Rata-rata waktu (jam) pelatihan per tahun untuk tiap karyawan, berdasarkan } \\
\text { kategori karyawan }\end{array}$ \\
\hline LA11 & $\begin{array}{l}\text { Program yang diarahkam untuk manajemen keterampilan dan pembelajaran } \\
\text { seumur hidup yang dapat menunjang karyawan untuk tetap berkarya dan } \\
\text { membantu mereka mengelolah perusahaanya }\end{array}$ \\
\hline LA12 & $\begin{array}{l}\text { Persentase karyawan yang menerima kajian regular kinerja dan pengembangan } \\
\text { karirnya }\end{array}$ \\
\hline LA13 & $\begin{array}{l}\text { Komposisi badan-badan tata kelola dan komposisi karyawan per kategori } \\
\text { berdasarkan jenis kelamin, kelompok umur, keanggotaan dalam kelompok } \\
\text { minoritas, dan indicator lain yang menunjukkan keberagaman }\end{array}$ \\
\hline LA14 & Rasio gaji pokok antara pria dan wanita berdasarkan kategori karyawan \\
\hline \multicolumn{2}{|c|}{ PPM Tanggung Jawab Produk } \\
\hline PR1 & $\begin{array}{l}\text { Siklus masa pakai dimana dampak kesehatan dan keselamatan hasil produksi } \\
\text { dinilai untuk upaya peningkatan, dan persentase kategori hasil produksi dan jasa } \\
\text { penting penting yang tunduk pada prosedur tersebut. }\end{array}$ \\
\hline PR2 & $\begin{array}{l}\text { Jumlah total insiden ketidakpatuhan pada peraturan dan inisiatif sukarela } \\
\text { lainnya tentang dampak kesehatan dan keselamatan hasil produk dan jasa, } \\
\text { selama siklus masa pakai, berdasarkan hasilnya }\end{array}$ \\
\hline PR3 & $\begin{array}{l}\text { Jenis informasi hasil produksi dan jasa yang dibutuhkan oleh prosedir tersebut, } \\
\text { dan persentase hasil produksi dan jasa penting yang harus mematuhi kebutuhan }\end{array}$ \\
\hline
\end{tabular}




\begin{tabular}{|l|l|}
\hline PR4 & $\begin{array}{l}\text { Jumformasi yang dimaksud } \\
\text { lainnya berkaitan dengan informasi dan label untuk hasil produksi dan jasa, } \\
\text { berdasarkan lainnya }\end{array}$ \\
\hline PR5 & $\begin{array}{l}\text { Praktek terkait kepuasan konsumen, termasuk hasil jajak pendapat untuk } \\
\text { mengatur kepuasan konsumen }\end{array}$ \\
\hline PR6 & $\begin{array}{l}\text { Program untuk ketaatan terhadap peraturan dan inisiatif sukarela lainnya, terkait } \\
\text { komunikasi pemasaran, termasuk iklan, promosi dan sponsorship berdasarkan } \\
\text { hasilnnya }\end{array}$ \\
\hline PR7 & $\begin{array}{l}\text { Jumlah total insiden ketidak-patuhan terhadap peraturan dan inisiatif sukarela } \\
\text { lainnya terkait, komunikasi pemasaran, termasuk iklan, promosi dan } \\
\text { sponsorship berdsarkan hasilnya }\end{array}$ \\
\hline PR8 & $\begin{array}{l}\text { Jumlah total pengaduan (2wdengan bukti) terkait pelanggaran privasi konsomen } \\
\text { dan hilangnya data konsumen }\end{array}$ \\
\hline PR9 & $\begin{array}{l}\text { Nilai moneter denda signifikan untuk ketidak patuhan terhadap hukum dan } \\
\text { peraturan, terkait provisi dan penggunaan hasil produksi dan jasa }\end{array}$ \\
\hline
\end{tabular}

Sumber:GRI G3

\section{Kerangka Konsep}

Kerangka konsep dibentuk untuk menunjukkan pengaruh variabel indevenden yaitu kinerja ekonomi, kinerja lingkungan, dan kinerja sosial terhadap variabel dependen kinerja keuangan seperti gambar berikut.

\section{Gambar 1. Kerangka Konsep}

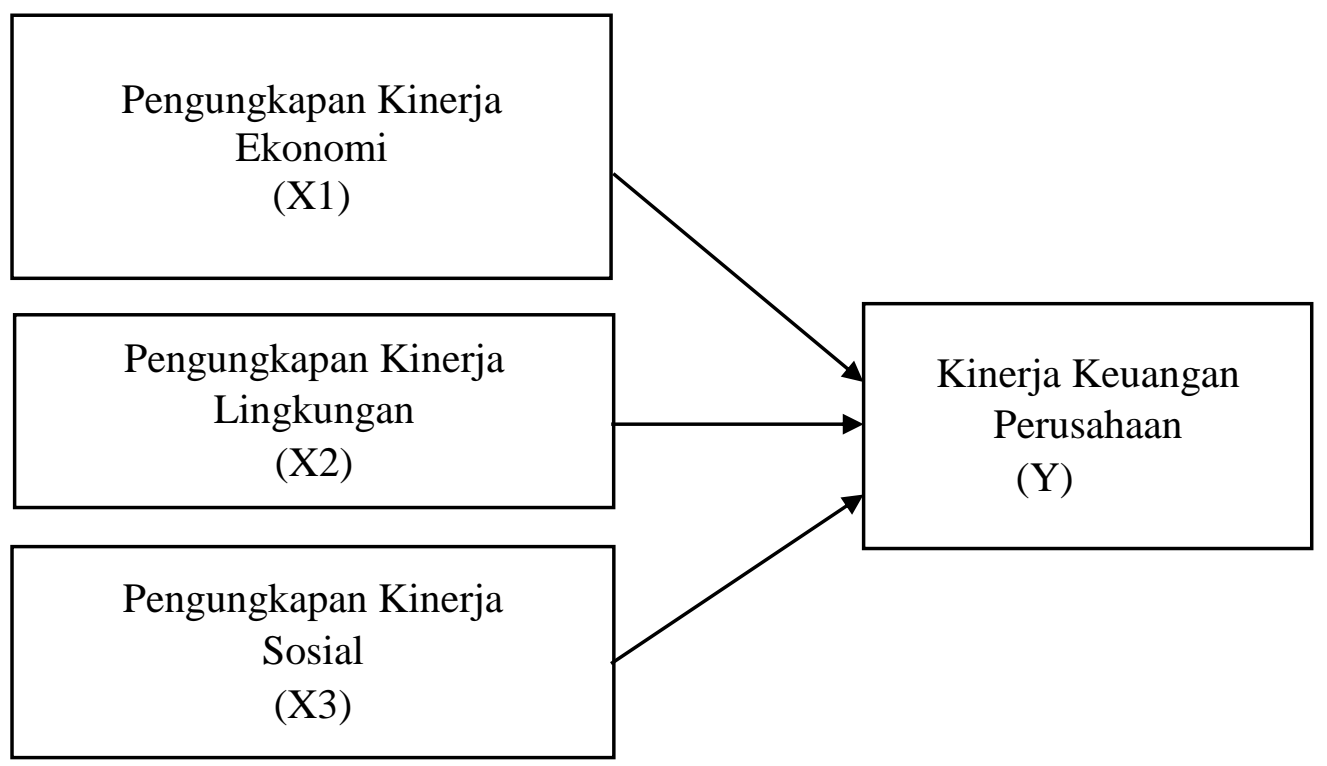




\section{Hipotesis}

Hipotesis merupakan jawaban sementara atas pemasalahan dalam objek penelitian. Berdasarkan perumusan masalah, maka hipotesis penelitian ini adalah:

H1 : Pengungkapan kinerja ekonomi berpengaruh positif terhadap kinerja keuangan.

H2 : Pengungkapan kinerja lingkungan berpengaruh terhadap kinerja keuangan.

H3 : Pengungkapan kinerja sosial berpengaruh positif terhadap kinerja keuangan.

\section{METODE PENELITIAN}

\section{Popolasi dan Sampel}

Populasi yang digunakan dalam penelitian ini adalah seluruh perusahaan yang terdaftar di Bursa Efek Indonesia pada tahun 2016-2018 yang berjumlah 23 perusahaan.

Pemilihan sampel ditentukan secara Purposive Sampling dengan tujuan untuk mendapatkan representatif sesuai dengan kriteria yang ditentukan. Kriteria untuk dipilih menjadi sampel adalah:

a. Perusahaan yang menerbitkan SR berturut-turut pada periode 20162018.

b. Perusahaan yang mengalami kerugian selama periode 2016-2018

c. Perusahaan yang tidak menggunakan mata uang rupiah.

\section{Operasionalisasi Variabel}

\section{a. Kinerja Keuangan (Y)}

Dalam penelitian ini, variabel dependen adalah kinerja keuangan. Menurut Fahmi (2011:2) kinerja keuangan adalah suatu analisis yang dilakukan untuk melihat sejauh mana perusahaan telah melaksanakan dengan menggunakan aturan-aturan pelaksaan keuangan secara baik dan benar. Kinerja keuangan dapat diukur dengan Return On Asset (ROA) yang merupakan bagian dari rasio profitabilitas. Return On Asset dapat dihitung dengan menggunakan rumus :

$$
\text { ROA }=(\text { Earning After Tax }) /(\text { Total Aktiva })
$$

\section{b. Kinerja Ekonomi $\left(\mathrm{X}_{1}\right)$}

Almilia dan Wijayanto (2007) menyatakan bahwa kinerja ekonomi adalah kinerja perusahaan-perusahaan secara relative berubah dari tahun ke tahun dalam suatu industri yang sama yang ditandai dengan return tahunan perusahaan. Kinerja ekonomi dapat dihitung dengan menggunakan : 
Rumus : $\frac{\text { kinerja ekonomi yang dilaporkan pada tahun } k e-n}{\text { jumlah yang wajib dilaporkan }} \times 100 \%$

\section{c. Kinerja Lingkungan $\left(\mathrm{X}_{2}\right)$}

Kinerja lingkungan adalah kinerja keuangan untuk ikut adil dalam melestarikan lingkungan. Kinerja lingkungan dibuat dalam bentuk peringkat oleh suatu lembaga yang berkaitan dengan lingkungan hidup Wibisno 2013). Kinerja lingkungan dapat dihitung dengan :

\section{d. Kinerja Sosial $\left(\mathbf{X}_{3}\right)$}

$$
\text { Rumus : } \frac{\text { kinerja lingkungan yang dilaporkan pada tahun } k e-n}{\text { jumlah yang wajib dilaporkan }} \times 100 \%
$$

Tanggung jawab sosial perusahaan seharusnya melampaui tindakan memaksimalkan laba untuk kepentingan pemegang saham (stakeholders), namun lebih luas lagi bahwa kesejahteraan yang dapat diciptakan olej perusahaan sebetulnya tidak terbatas kepada kepentingan pemegang sahm,tetapi juga untuk kepentingan stakeholders,yaitu semua pihak yang mempunyai keterkaitan atau klaim terhadap perusahaan (Untung,2008 dalam Waryanti,2009). Kinerja sosial dapat dihitung dengan menggunakan rumus:

$$
\text { Rumus : } \frac{\text { kiner ja sosial yang dilaporkan pada tahun } k e-n}{\text { jumlah yang wajib dilaporkan }} \times 100 \%
$$

\section{Teknis Analisis Data}

Teknis analisis data yang digunakan dalam penelitian ini adalah analisis regresi linear berganda. Teknik analisis linear berganda berguna untuk menguji hipotesis tentang pengaruh variabel indevenden. Penelitian ini menggunakan teknik analisis regresi linear berganda untuk mengetahui besarnya pengaruh variabel independen terhadap variabel devenden dengan model dasar sebagai berikut:

Dimana :

\begin{tabular}{|c|c|}
\hline Y & $=$ Kinerja Keuangan \\
\hline $\mathrm{a}$ & $=$ Konstanta \\
\hline $\mathrm{X}_{1}$ & $=$ Kinerja ekonomi \\
\hline $\mathrm{X}_{2}$ & $=$ Kinerja lingkungan \\
\hline $\mathrm{X}_{3}$ & = Kinerja sosial \\
\hline $\mathrm{b}_{1}, \mathrm{~b}_{2}, \mathrm{~b}_{3}$ & $=$ Koefisien regresi parsial untuk $X_{1}, X_{2}, X_{3}$ \\
\hline e & $=$ Tingkat kesalahan dalam estimasi (error) \\
\hline
\end{tabular}

$$
\mathrm{Y}=\mathrm{a}+\mathrm{b}_{1} \mathrm{X}_{1}+\mathrm{b}_{2} \mathrm{X}_{2}+\mathrm{b}_{3} \mathrm{X}_{3}+\mathrm{e}
$$




\section{HASIL PENELITIAN DAN PEMBAHASAN}

1. Uji Asumsi Klasik

a. Uji Normalitas Data

Uji normalitas bertujuan untuk menguji apakah dalam model regresi variabel devenden dan variabel indevenden berdistribusi normal. Uji normalitas yang digunakan adalah grafik histogram dan normal Probability plot dan kolmogrov-smirnov.

Tabel. 1 Hasil Uji Normalitas Data dengan Uji Kolmogrov- Smirnov One-Sample Kolmogorov-Smirnov Test

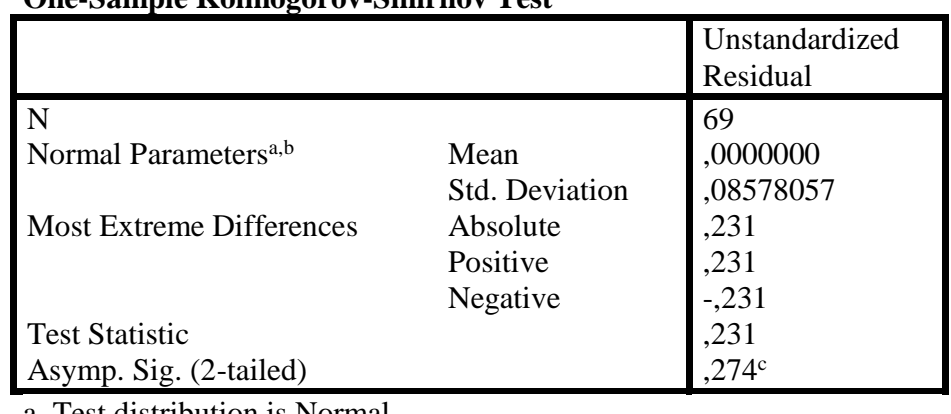

a. Test distribution is Normal.

b. Calculated from data.

c. Lilliefors Significance Correction.

Sumber : Hasil Output SPSS 22 (data diolah)

Pada tabel 1 diatas terlihat bahwa besarnya signifikan lebih dari 5\% $(0,05)$ yaitu signifikannya sebesar $0,274 \quad(27 \%)$ maka data tersebut terdistribusi normal.

\section{b. Uji Multikolonieritas}

Uji multikolonieritas bertujuan untuk mengetahui korelasi linear antara dua atau lebih variabel indevenden yang digunakan dalam penelitian ini. Uji dilakukan dengan Tolerance Value dan Variance Inflation Factor (VIF). Agar tidak terjadi multikolonieritas, batas Tolerance Value > 0,10 dan VIF <10. Adapun hasil uji multikolonieritas pada peneltian ini dapat dilihat pada tabel dibawah ini:

Tabel 2 Uji Multikolonieritas Coefficients $^{\mathrm{a}}$

\begin{tabular}{|ll|l|l|}
\hline \multirow{2}{*}{ Model } & \multicolumn{3}{|l|}{ Collinearity Statistics } \\
\cline { 3 - 4 } & & & \\
\hline 1 & (Colerance & VIF \\
\cline { 2 - 4 } & Kinerja Ekonomi &, 991 & \\
& Kinerja Lingkungan &, 993 & 1,009 \\
& Kinerja Sosial &, 999 & 1,007 \\
& &
\end{tabular}

a. Dependent Variable: Kinerja Keuangan

Sumber : hasil olahan SPSS 22 
Berdasarkan tabel 2 diatas dapat dilihat bahwa Tolerance Value $>0,10$ dan $\mathrm{VIF}<10$, sehingga dapat disimpulkan bahwa diantara variabel bebas tersebut tidak terdapat hubungan multikolonieritas. Dari uji ini dapat disimpulkan bahwa semua variabel bebas yang digunakan dalam penelitian ini lolos uji gejala multikolonieritas.

c. Uji Heteroskedastisitas

Gambar 2 Hasil Uji Heteroskedastisitas

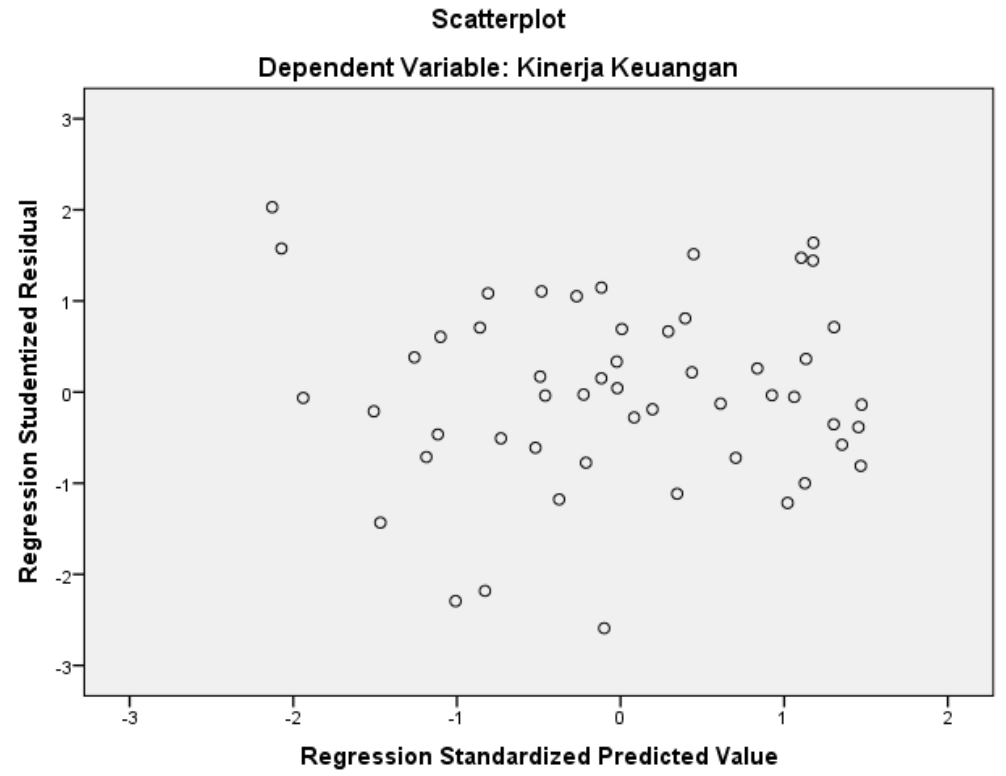

Sumber : Hasil olahan SPSS22

Dari scatterplot dapat diketahui bahwa titik-titik menyebar dengan pola yang tidak jelas diatas dan dibawah angka 0 pada sumbu $Y$. Bedasarkan data tersebut maka tidak terjadi masalah heteroskedastisitas pada model regresi ini.

d. Uji Autokorelasi

Tabel 3 Hasil Uji Autokorelasi (Uji Durbin-Watson)

Model Summary ${ }^{b}$

\begin{tabular}{|l|l|l|l|l|l|}
\hline Model & $\mathrm{R}$ & R Square & Adjusted R Square & $\begin{array}{l}\text { Std. Error of the } \\
\text { Estimate }\end{array}$ & Durbin-Watson \\
\hline 1 &, $662^{\mathrm{a}}$ &, 438 &, 430 &, 06526531 & 1,950 \\
\hline
\end{tabular}

a. Predictors: (Constant), Kinerja Sosial, Kinerja Lingkungan, Kinerja Ekonomi

b. Dependent Variable: Kinerja Keuangan

Sumber : hasil olahan SPSS22 
Berdasarkan hasil tabel diatas, dapat dilihat bahwa nilai DurbinWatson (DW) sebesar 1,760. Taraf signifikan 0,05 dengan jumlah sampel penelitian $(\mathrm{n})=69$ dan jumlah variabel independen $3(\mathrm{k}=3)$ maka tabel Durbin-Watson (DW) akan memberikan nilai batas atas dU (upper) $=1,7015$. Dimana nilai $\mathrm{dW}=1,950$ lebih besar dari batas atas $\mathrm{dU}=$ 1,7015 dan kurang dari 4-dU (4-1,7015=2,2985). Hasil tersebut menunjukkan bahwa tidak terjadi autokorelasi pada model regresi penelitian ini.

\section{Model Penelitian}

\section{a. Uji Regresi Linear Berganda}

Analisis linear berganda diginakan untuk mengetahui pengaruh kinerja ekonomi, lingkungan dan sosial terhadap kinerja keuangan . analisis ini diolah dengan program SPSS 22. Hasil analisis regresi linear berganda ditinjukkan pada tabel berikut:

\section{Tabel 4 Tabel Analisis Regresi Linear Berganda}

\begin{tabular}{|ll|l|l|}
\hline \multirow{2}{*}{ Model } & \multicolumn{2}{|l|}{ Unstandardized Coefficients } \\
\cline { 3 - 4 } & & $\mathrm{B}$ & Std. Error \\
\hline 1 & (Constant) & $-1,639$ &, 373 \\
& Kinerja Ekonomi &, 914 &, 173 \\
& Kinerja Lingkungan &, 206 &, 123 \\
& Kinerja Sosial &, 366 &, 093 \\
\hline
\end{tabular}

Sumber : hasil olahan SPSS22

Berdasarkan tabel diatas, maka diperoleh persamaan regresi sebagai berikut:

$$
\mathrm{Y}=-1,639+0,914 \mathrm{X}_{1}+0,206 \mathrm{X}_{2}+0,366 \mathrm{X}_{3}+\mathrm{e}
$$

Interpretsai dari persamaan regresi linear berganda tersebut adalah sebagai berikut:

1) Nilai konstanta adalah -1,639 artinya variabel $X_{1}($ Kinerja Ekonomi), $\mathrm{X}_{2}$ (Kinerja Lingkungan), $\mathrm{X}_{3}$ (Kinerja Sosial) bernilai 0 , maka nilai variabel Y (Kinerja Keuangan) akan menurun sebesar 1,639 .

2) Nilai koefisien kinerja ekonomi adalalah 0,914 artinya setiap kenaikan kinerja ekonomi $1 \%$ akan meningkatkan kinerja keuangan sebesar 0,914 atau 91,4\%. 
3) Nilai koefisien kinerja lingkungan adalah 0,206 artinya setiap kenaikan kinerja lingkungan $1 \%$ akan meningkatkan kinerja keuangan sebesar 0,206 atau 20,6\%.

4) Nilai koefisien kinerja sosial adalah 0,366 artinya setiap kenaikan kinerja sosial $1 \%$ akan meningkatkan kinerja keuangan sebesar 0,366 atau $36,6 \%$.

\section{b. Uji Koefisien Determinasi $\left(\mathbf{R}^{\mathbf{2}}\right)$}

Analisis determinasi dalam regresi linear berganda digunakan untuk mengetahui persentase. Sumbangan pengaruh kinerja ekonomi, lingkungan dan sosial terhadap kinerja keuangan. Koefisien ini menunjukkan seberapa besar persentase perusahaan variasi variabe, independen yang digunakan dalam model mampu menjelaskan variasi variabel dependen.

\section{Tabel 5 Uji Koefisien Determinasi $\left(\mathbf{R}^{2}\right)$}

\begin{tabular}{|l|l|l|l|l|}
\hline Model & R & R Square & Adjusted R Square & $\begin{array}{l}\text { Std. Error of the } \\
\text { Estimate }\end{array}$ \\
\hline 1 &, $662^{\mathrm{a}}$ &, 438 &, 430 & 1.950 \\
\hline
\end{tabular}

a. Predictors: (Constant), Kinerja Sosial, Kinerja Ekonomi, Kinerja Lingkungan

b. Dependent Variable: Kinerja Keuangan

Sumber : Hasil olahan data SPSS 22

Berdasarkan tabel diatas, besarnya Adjusted $\mathrm{R}$ Squareyang diperoleh sebesar 0,438 hal ini berarti kinerja ekonomi, kinerja lingkungan dan kinerja sosial bersama-sama mempengaruhi variabel devenden yaitu kinerja keuangan sebesar 43,8\%. Sedangkan sisanya sebesar 56,2\% (100\%-43,8\%) dijelaskan oleh variabel-variabel lain diluar penelitian.

\section{Pengujian Hipotesis}

\section{a. Uji Parsial (Uji Statistik t)}

Uji $\mathrm{t}$ dilakukan untuk mengetahui hubungan antara variabelvariabel independen terhadap variabel dependen secara parsial (individu). Dengan menggunakan tingkat signifikan $(\alpha=5 \%)$, jika nilai signifikan $\mathrm{t}>$ 0,05 maka hipotesis ditolak, artinya tidak terdapat pengaruh yang signifikan secara parsial dari variabel independen terhadap variabel dependen. Sebaliknya, jika nilai signifikan $\mathrm{t}<0,05$ maka hipotesis diterima, artinya terdapat pengaruh yang signifikan secara parsial dari variabel independen dan variabel dependen. Berikut ini adalah hasil pengujian secara parsial (uji t) : 


\section{Tabel 6 Uji Parsial}

\section{Coefficients $^{\mathrm{a}}$}

\begin{tabular}{|ll|l|l|l|l|l|}
\hline \multirow{2}{*}{ Model } & \multicolumn{2}{l|}{$\begin{array}{l}\text { Unstandardized } \\
\text { Coefficients }\end{array}$} & $\begin{array}{l}\text { Standardized } \\
\text { Coefficients }\end{array}$ & & \\
\cline { 2 - 4 } & $\mathrm{B}$ & Std. Error & Beta & T & Sig. \\
\hline 1 & (Constant) & $-1,639$ &, 373 & & $-4,395$ &, 000 \\
& Kinerja Ekonomi &, 914 &, 173 &, 545 & 5,276 &, 000 \\
& Kinerja Lingkungan &, 206 &, 123 &, 173 & 1,672 &, 526 \\
\multicolumn{2}{|l|}{ Kinerja Sosial } &, 366 &, 093 &, 404 & 4,924 &, 000 \\
\hline
\end{tabular}

a. Dependent Variable: Kinerja Keuangan

Sumber : hasil olahan SPSS22

Berdasarkan tabel 6 dapat dijelaskan beberapa hal sebagai beriku:

1) Berdasarkan tabel diatas dapat hasil uji t parisal dalam regresi linear berganda pada variabel kinerja ekonomi(X1) 0,5276 dengan nilai signifikan sig, sebesar $0,000 \quad($ sig $<0,05)$ maka dapat disimpulkan bahwa kinerja ekonomi (X1) berpengaruh positif dan signifikan terhadap kinerja keuangan.

2) Berdasarkan tebael diatas dapat dilihat hasil uji t parsial dalam regersi linear berganda pada variabel kinerja lingkungan (X2) 1,672 dengan nilai signifikan sig. sebesar 0,526 (sig >0,05) maka dapat disimpulkan bahwa kinerja lingkungan (X2) tidak berpengaruh terhadap kinerja keuangan.

3) Berdasarkan tebael diatas dapat dilihat hasil uji t parsial dalam regersi linear berganda pada variabel kinerja sosial (X3) 4,924 dengan nilai signifikan sig. sebesar $0,000 \quad($ sig $<0,05)$ maka dapat disimpulkan bahwa kinerja sosial (X3) berpengaruh positif dan signifikan terhadap kinerja keuangan.

\section{b. Uji Simultan (Uji Statistik F)}

Pengujian ini bertujuan untuk mengetahui pengaruh antara variabel independenterhadap variabel dependen secara bersama-sama (simultan), signifikansi model regresi secara simultan diuji dengan melihat perbandingan antara $\mathrm{f}$ tabel dengan $\mathrm{f}$ hitung. Selain itu akan dilihat nilai signifikansi, dimana jika nilai signifikan dibawah 0,05 maka variabel independen dinyatakan berpengaruh terhadap variabel dependen. Hasil penelitian ini ditunjukkan pada tabel berikut ini: 


\section{Tabel 7 Uji Statistik F}

ANOVA $^{\mathrm{a}}$

\begin{tabular}{|ll|l|l|l|l|l|}
\hline Model & & Sum of Squares & Df & Mean Square & F & Sig. \\
\hline 1 & Regression & 45,478 & 3 & 15,159 & 14,764 &, $000^{\mathrm{b}}$ \\
& Residual & 49,285 & 48 & 1,027 & & \\
& Total & 94,763 & 51 & & & \\
\hline
\end{tabular}

a. Dependent Variable: Kinerja Keuangan

b. Predictors: (Constant), Kinerja Sosial, Kinerja Ekonomi, Kinerja Lingkungan

Sumber: Hasil olahan SPSS 22

Berdasarkan tabel 7 diatas hasil uji $\mathrm{F}$ simultan dalam regresi linear berganda nilai sig, sebesar 0,000 ( $\operatorname{sig}<0,05)$, maka pengambilan keputusan berdasarkan uji $\mathrm{F}$ dapat disimpulkan bahwa bahwa kinerja ekonomi, kinerja lingkungan dan kinerja sosial secara bersama-sama berpengaruh signifikan terhadap kinerja keuangan. Jadi hipotesis yang diajukan peneliti diterima.

\section{Pembahasan}

a. Pengaruh Kinerja Ekonomi terhadap Kinerja Keuangan

Dilihat dari koefisien regresinya diketahui bahwa kinerja ekonomi pengaruh terhadap kinerja keuangan dengan demikian menunjukkan kinerja ekonomi memiliki pengaruh terhadap kinerja keuangan yang diproksikan dengan Return on Asset, maka $\mathrm{H}_{1}$ diterima pada kinerja keuangan. Hasil penelitian ini konsisten dengan penelitian William (2014) yang menemukan bahwa kinerja ekonomi yang terdapat di dalam SR perusahaan akan meningkatkan transparasi perusahaan, yang akan meningkat pula image perusahaan. Hasil penelitian ini konsisten dengan penelitian oleh Lianur Atika (2016) yang menemukan bahwa kinerja ekonomi yang terdapat SR memiliki pengaruh terhadap kinerja keuangan. Sirega (2008) yang menemukan bahwa kinerja ekonomi memiliki pengaruh signifikan terhadap Return on Asset, kinerja ekonomi yang terdapat di dalam SR semakin luas pengungkapan yang dilakukan perusahaan akan dapat memberikan Return on Asset yang lebih besar pada perusahaan pada kondisi keuangan satu tahun kedepan.

\section{b. Pengaruh Kinerja Lingkungan terhadap Kinerja Keuangan}

Kinerja lingkungan menunjukkan bahwa tidak berpengaruh terhadap kinerja keuangan yang diproduksikan dengan Return on Asset, maka $\mathrm{H}_{0}$ ditolak pada kinerja keuangan. Penelitian Adams et al (2010) 
yang mengungkapkan bahwa Sr akan mempengaruhi respon pasar, setelah mempengaruhi respon pasar dan perilaku investor barulah SR atau dalam hal ini secara khusus adalah kinerja lingkungan akan mempengaruhi kinerja keuangan. Hal ini akan berpengaruh terhadap pendapatan dan laba perusahaan yang merupakan indikator dari kinerja keuangan. Itulah alasan mengapa kinerja lingkungan tidak memiliki pengaruh terhadap kinerja keuangan. Menurut Sarumpaet (2005), tidak ada hubungan antara kinerja lingkungan dan kinerja keuangan. Hal ini disebabkan produk dan jasa yang ditawarkan perusahaan berkinerja lingkungan tinggi lebih mahal yang tidak sesuai dengan sifat konsumen Indonesia. Penelitian Rakhiemah dan Agustia (2008), juga mendukung penelitian Sarumpaet bahwa kinerja lingkungan bukan sebagai faktor dominan dalam menentukan harga saham dan besarnya dividen.

\section{c. Pengaruh Kinerja Sosial terhadap Kinerja Keuangan}

Kinerja sosial memiliki pengaruh terhadap kinerja keuangan yang diproksikan dengan Return on Asset, maka $\mathrm{H}_{1}$ diterima pada kinerja keuangan. Hasil penelitian Tarigan dan Samuel (2014) mengungkapkan bahwa dengan melaksanakan dan melaporkan tanggung jawab sosial terhadap para pemangku kepentingan tidak hanya dapat meningkatkan harga saham rata-rata perusahaan, tetapi juga dapat meningkatkan kesejahteraan dan loyalitas karyawan, menurunkan tingkat perputaran karyawan sehingga dapat berujung pada meningkatnya produktivitas perusahaan. Semakin meningkatnya produktivitas perusahaan, maka akan berdampak pada peningkatan kinerja karyawan tersebut, maka akan memungkinkan nilai pasar perusahaan meningkat, sehingga kinerja perusahaan akan dinilai baik oleh stakeholder. Dan sebuah perusahaan yang dipandang oleh stakeholdernya memiliki reputasi yang baik akan membuat perusahaan lebih mudah melewati mekanisme pasar untuk mendapatkan posisi keuangan yang baik. Studi literatur yang dilakukan oleh Finch (2005), dalam Dahlia dan Siregar (2008), dikatakan bahwa tujuan perusahaan menggunakan sustainability reporting framework adalah sebagai cara yang digunakan perusahaan untuk mengelola hubungan dengan stakeholdernya. Dengan pengungkapan Sustainability Report yang dilakukan perusahaan diharapkan dapat memberikan bukti nyata bahwa proses produksi yang dilakukan perusahaan tidak hanya berorientasi keuntungan, tetapi juga memperhatikan isu sosial, dan lingkungan, sehingga dapat meningkatkan kepercayaan stakeholder yang akan 
berdampak pada peningkatan nilai perusahaan melalui peningkatan investasi yang berdampak pada peningkatan laba perusahaan.

\section{KESIMPULAN DAN SARAN}

\section{Kesimpulan}

Dari hasil penelitian analisis dan uji hipotesis yang telah dilakukan, peneliti mengambil kesimpulan sebagai berikut:

a. Variabel kinerja ekonomi berpengaruh positif signifikan terhadap kinerja keuangan.

b. Variabel kinerja lingkungan tidak berpengaruh positif signifikan terhadap kinerja keungan.

c. Variabel kinerja sosial berpengaruh positif signifikan terhadap kinerja keuangan.

\section{Saran}

Berdasarkan kesimpulan dan keterbatasan penelitian tersebut adapun saran yang dapat diberikan oleh peneliti untuk penelitian selanjutnya yaitu:

a. Memperhatikan kriteria pemilihan sampel, perusahaan yang digunakan tidak hanya perusahaan yang terdaftar di BEI, misalnya dapat menggunakan perusahaan BUMN yang sudah menerbitkan sustainability report.

b. Dapat mengggunakan pedoman terbaru yang sudah disesuaikan dengan kondisi perusahaan di indonesia selain GRI untuk mengukur pengungkapan sustainability report agar hasilnya lebih sesuai dengan kondisi perusahaan.

\section{DAFTAR PUSTAKA}

Agnes Sawir. 2005. Analisis Kinerja Keuangan dan Perencanaan Keuangan. Jakarta: PT Gramedia Pustaka Utama.

Almia, L,. Spica. Dan D. Wijayanto.2007. Pengaruh Environmental Performance dan Environmental Disclosure Terhadap Economical Performance. Procedings The 1st Accounting Confrrence, Depok, 7-9 November 2007. pp.1-23

Eko Nofianto, Linda Agustina.2014. Analisis Pengaruh Sustainability Report Terhadap Kinerja Keuangan Perusahaan. Jurusan Akuntansi, Fakultas Ekonomi, Universitas Negeri Semarang, Indonesia. Accounting Analysis Journal. ISSN 2252-6765. 
Elkington, John. 1997. Cannibals with forks, the triple bottom line in 21 st Century Business. Oxford:captune

Fahmi, 2011: 2 Analisis Laporan Keuangan. Lampudo: ALFABETA

Freeman, R. Edward dan John McVea. 2001. Strategic Management: A Stakeholder Approach. SSRN Electronic Journal. Darden Graduate School of Business Administration, University of Virginia.

Global report Initiative (GRI).2013. Sustainability reporting Guidelines. www.globalreporting.org

Ghozali, Imam, 2016. Aplikasi Analisis Multivariance dengan program SPSS. Semarang: Badan Penerbit Universitas Diponegoro.

Gray, R., Kouhy, R., dan Lavers, S. 1992. Corperate Social and Environmental Reporting: A Review of the Literarur and a Longituditinal Study of UK disclosure. Accounting Auditing \& Accountibility Journal, 8, 47-77

Hackston, David dan MJ. Milne, 1996. Same Determinants of Social and Environmental Disclouser in New Zealand Companies, Accounting, Auditing and Accounting Vo;. 9 No \. 1.p. 77-100

Junita Simbolon dan Dr.H.Memed Sueb, 2016. Pengaruh Pengungkapan Sustainability Report terhadap Kinerja Keuangan perusahaan (Stdudi Empiris pada Perusahaan Tambang dan Infrastruktur Subsektor Energi yang Terdaftar di BEI tahun 2010-2014) Paper Simposium Nasional Akuntansi XIX, Lampung 2016.

Kieso, 2010.Intermediate Accounting:IFRS Edition: John Wiley \& Sons.

Leal, G,G, Marti Casadesus, dan Pasola, 2003 Using Environmental Management System to Increase Firms Competitiness. Corperate Social Responsibility and Environmental Management, 10,101-110

Mariana Sitinjak.2018. Pengaruh Pengungkapan Kinerja Ekonomi, Lingkungan dan Sosial Terhadap Kinerja Keuangan Pada Perusahaan yang Terdaftar di Bursa Efek Indonesia tahun 20132017. Skripsi. Universitas Katolik Santo Thomas Sumatera Utara.

Nofianto Eko, Agustina Linda. 2014 . Analisis Pengaruh Sustainability Report Terhadap Kinerja Keuangan Perusahan. Accounting Analysis Journal. Universitas Negeri Semarang. Vol. 3. No. 3.

Otoritas Jasa Keuangan. (2017). Strategi Nasional Literasi Keuangan Indonesia (Revisit 2017).19 Maret 2018. www.ojk.go.id 
Puji Astuti,2019. Pengaruh Pengungkapan Sustainability Report Terhadap Kinerja Keuangan Perusahaan (Studi Empiris pada Perusahaan yang Terdaftar di Index Saham Syariah Indonesia Tahun 20162018) Skripsi Fakultas Ekonomi dan Bisnis Islam. Universitas Islam Negeri Raden Intan Lampung 1441 H / 2019 M.

Ria Natalia dan Josua Tarigan.2014.Pengaruh Sustainability Reporting Terhadap Kinerja Keuangan Perusahaan Publik dari Sisi Profitability Ratio Akuntansi Bisnis Universitas Kristen Petra

Sabrina dan Lukman. 2019. Pengaruh Sustainability Report Terhadap Kinerja Keuangan Perusahaan Perbankan. Jurnal Multiparadigma Akuntansi, Volume I No. 2/2019 Hal: 477-486.

Sarkar 2008. Public Policy and Corperate Environmental Behaviour: Broader View. Corperate Social responsibility and Environmental Management.15, 281-297

Sejati dan Prastiwi (2015). Pengaruh Pengungkapan Sustainability Report Terhadap Kinerja dan Nilai Perusahaan. Diponegoro Journal Of Accounting.Semarang 